\title{
Carbon dioxide availability, intracellular pH and growth rate of the coccolithophore Emiliania huxleyi
}

\author{
N. A. Nimer ${ }^{1}$, C. Brownlee ${ }^{2}$, M. J. Merrett ${ }^{1}$ \\ ${ }^{1}$ School of Biological Sciences, University College of Swansea, Singleton Park, Swansea SA2 8PP, United Kingdom \\ ${ }^{2}$ Marine Biological Association, The Laboratory, Plymouth PL1 2PB, United Kingdom
}

\begin{abstract}
Growth of a high-calcifying strain of Emiliania huxleyi (Lohmann) Hay \& Mohler was investigated in cultures aerated with varying concentrations of $\mathrm{CO}_{2}$ in air and compared with growth in $0.03 \%(\mathrm{v} / \mathrm{v}) \mathrm{CO}_{2}$. Cultures aerated with $0.1 \%(\mathrm{v} / \mathrm{v}) \mathrm{CO}_{2} /$ air under identical conditions resulted in approximately $40 \%$ reduction in cell number and final cell yield. A concentration of $0.5 \%(\mathrm{v} / \mathrm{v}) \mathrm{CO}_{2}$ completely inhibited growth. In the virtual absence of $\mathrm{CO}_{2}$, cells could grow to the same levels as in those cultures aerated with air-equilibrated levels of $\mathrm{CO}_{2}$, i.e. $0.03 \%(\mathrm{v} / \mathrm{v}) \mathrm{CO}_{2}$. Measurement of internal $\mathrm{pH}\left(\mathrm{pH}_{1}\right)$ gave comparable results using either the 5,5 -dimethyl-2 $\left[{ }^{14} \mathrm{Cloxazalidine-2,4-dione}\right.$ (DMO) method or a fluorescent probe technique (BCECF-AM). At external $\mathrm{pH} 8.3$, intracellular $\mathrm{pH}$ of cells aerated with air was 6.9 whilst $\mathrm{pH}_{1}$ of cells aerated with $0.1 \%(\mathrm{v} / \mathrm{v}) \mathrm{CO}_{2}$ was 6.4 . Lowering external $\mathrm{pH}$ decreased growth rate for cultures aerated with $0.03 \cdot \mathrm{v}(\mathrm{v} / \mathrm{v}) \mathrm{CO}_{2} . \mathrm{A} 30 \%$ reduction in cell number and final cell yield occurred at $\mathrm{pH} 7.8$ increasing to almost $60 \%$ at $\mathrm{pH} 7.0 ; \mathrm{pH}_{1}$ decreased at more acidic external $\mathrm{pH}$ down to 6.38 at $\mathrm{pH} 7.0$. Carbon dioxide concentration and external $\mathrm{pH}$ appear to be equally important in the growth of high-calcifying cells. The significance of these results is considered in relation to the development of mesoscale blooms of $E$. huxleyi.
\end{abstract}

KEY WORDS: Emiliania huxleyi Growth - Inorganic carbon - Intracellular pH

\section{INTRODUCTION}

Metabolic processes in microalgal cells are compartmentalized at the intracellular level, the proton concentration being maintained within narrow limits in the various compartments. The homeostasis of $\mathrm{pH}$ at all levels of cellular organisation is achieved by the balance between the rates of proton-producing and proton-consuming reactions and fluxes of $\mathrm{H}^{+}$or $\mathrm{OH}^{-}$ through various transporters in conjunction with passive diffusion pathways (Haussinger et al. 1988, Tester 1990).

The internal $\mathrm{pH}\left(\mathrm{pH}_{1}\right)$ in Emiliania huxleyi (Lohmann) Hay \& Mohler cells has to be precisely regulated because the high-and low-calcifying strains show a negative membrane potential (Sikes \& Wilbur 1982), as with all cells growing in seawater (Nimer et al. 1992). This will lead to the passive diffusion of protons into the cytosol, thus altering the $\mathrm{pH}_{\mathrm{i}}$. But this passive dif- fusion depends on the $\mathrm{H}^{+}$permeabilities of the plasmalemma and the proton electrochemical gradient $\left(\Delta \mu \mathrm{H}^{+}\right)$, where $\Delta \mu \mathrm{H}^{+}=\mathrm{E}_{\mathrm{m}}+58\left(\mathrm{pH}_{\mathrm{e}}-\mathrm{pH}_{1}\right)=(-60)+$ $58(8-7.3)=-60+41=-19 \mathrm{mV}$ [where $\mathrm{pH}_{\mathrm{e}}$ is external $\mathrm{pH}$, and $\mathrm{E}_{\mathrm{m}}=\mathrm{RT} / 3 \mathrm{~F}$ where $\mathrm{R}$ is gas constant, $\mathrm{T}$ is temperature $(\mathrm{K})$ and $\mathrm{F}$ is Faraday constant] so the inward driving force for $\mathrm{H}^{+}$is very small. Both $\mathrm{H}^{+}$consuming reactions (including $\mathrm{NO}_{3}{ }^{-}, \mathrm{SO}_{4}{ }^{2-}$ reduction, DMSP production) and $\mathrm{H}^{+}$producing reactions (Raven \& Smith 1974,1976 ) occur in microalgae and, in the case of $E$. huxleyi, this includes biologically driven intracellular calcification (Brownlee et al. 1994b), so a pH regulating mechanism is needed to counteract acidification of the cytosol.

In microalgae, $\mathrm{CO}_{2}$ is the substrate for ribulose biphosphate carboxylase (Rubisco), but in highcalcifying cells of Emiliania huxleyi, $\mathrm{HCO}_{3}{ }^{-}$provides the inorganic carbon substrate for calcification (Sikes et al. 1980). In microalgae capable of the direct utiliza- 
tion of $\mathrm{HCO}_{3}^{-}$as the exogenous inorganic carbon source for photosynthesis (Rees 1984, Patel \& Merrett 1986, Dixon et al. 1987, Nimer \& Merrett 1992), $\mathrm{pH}_{\mathrm{i}}$ is expected to be an important factor in maintaining the $\mathrm{CO}_{2} / \mathrm{HCO}_{3}^{-}$equilibrium within the cytosol. In high-calcifying cells of E. huxleyi, $\mathrm{H}^{+}$fluxes at the Golgi/coccolith vesicle membrane will be important in relation to $\mathrm{HCO}_{3}{ }^{-}$availability (Brownlee et al. 1994b). Since there is a close relationship between calcification and photosynthesis (Nimer \& Merrett 1994b) cytosolic $\mathrm{pH}$ may be important in relation to the availability of inorganic carbon to Rubisco in the chloroplast.

Many species of marine phytoplankton will grow well when aerated with air enriched with $\mathrm{CO}_{2}$ (Shiraiwa et al. 1988, Umino et al. 1991) but high-calcifying cells of Emiliania huxleyi failed to grow when aerated with air enriched with $0.5 \%(\mathrm{v} / \mathrm{v}) \mathrm{CO}_{2}$. If the cells are unable to utilize this extra $\mathrm{CO}_{2}$, the high ambient $\mathrm{CO}_{2}$ concentrations will result in the the passive diffusion of $\mathrm{CO}_{2}$ across the plasmalemma and acidification of the cytosol.

The $\mathrm{pH}_{1}$ in cyanobacteria (Falkner et al. 1976, Coleman \& Colman 1981) and green algae (Lane \& Burris 1981, Tromballa 1983, Gimmler et al. 1988, Goyal \& Gimmler 1989), has been measured using 5,5dimethyl-2[ ${ }^{14} \mathrm{C}$ loxalidine-2,4-dione (DMO), while the fluorescent probe $2^{\prime}, 7^{\prime}$-bis-(2 carboxyethyl)-5 (and -6) carboxyfluorescein acetoxymethyl ester (BCECF-AM) has been used in conjunction with dual wavelength fluorescence microscopy to measure the $\mathrm{pH}_{1}$ in lowcalcifying cells of Emiliania huxleyi (Dixon et al. 1989). In the present study the 2 methods are compared and used to investigate possible potential interactions between inorganic carbon availability, $\mathrm{pH}_{1}$ and growth.

\section{METHODS}

Growth of cells. Axenic cultures of a high-calcifying strain of Emiliania huxleyi (Bigelow Laboratories No. $88 \mathrm{E}$ ) were grown on the same medium as described previously (Nimer \& Merrett 1992) using an initial inoculum of $10^{5}$ cells $\mathrm{ml}^{-1}$. When required, the $\mathrm{pH}$ of the medium was maintained using $\mathrm{N}$-[tris(hydroxymethyl)-methyl] glycine (Tricine) for $\mathrm{pH}$ at 8.3 and 2-hydroxy-1-piperazine ethanesulfonic acid (HEPES) for $\mathrm{pH} 7.8$ and 7.0 . Cultures were gently aerated with air $\left(0.03 \% \mathrm{v} / \mathrm{v} \mathrm{CO}_{2}\right)$ or $\mathrm{CO}_{2}$-enriched air $\left(0.1 \%\right.$ and $\left.0.5 \% \mathrm{v} / \mathrm{v} \mathrm{CO}_{2}\right)$ using a gas blender 852 (Signal Instrument Company Limited, Surrey, UK) at a flow rate of approximately $1 \mathrm{l} \mathrm{h}^{-1}$ and grown at $15^{\circ} \mathrm{C}$ at a photon flux density of $50 \mu \mathrm{mol} \mathrm{m} \mathrm{m}^{-2}$ $\mathrm{s}^{-1}$ at the surface provided by cool white fluorescent lamps. At this flux density the growth rate was 0.5 divisions $\mathrm{d}^{-1}$ (see Fig. 2) compared with 1.5 divisions $\mathrm{d}^{-1}$ at higher photon flux densities (Brand 1982).
Carbon starved cells. Harvested cells were resuspended in fresh medium lacking $\mathrm{NaHCO}_{3}$ and the suspension incubated at $20^{\circ} \mathrm{C}$ in a Clark-type oxygen electrode (Hansatech, Ltd, Kings Lynn, Norfolk, UK) at a photon flux of $500 \mu \mathrm{mol} \mathrm{m} \mathrm{m}^{-2} \mathrm{~s}^{-1}$ (Ellipsoid Halogen reflector bulb, Philips, Eindhoven, The Netherlands). The chamber was closed and the cells were allowed to deplete all endogenous carbon sources as measured by the cessation of oxygen evolution (compensation point). Over the relatively short period (ca 30 to $45 \mathrm{~min}$ ) required to take cells to the compensation point, photoinhibition of inorganic-carbon-dependent photosynthetic oxygen evolution was not observed.

Measurement of internal $\mathrm{pH}\left(\mathrm{pH}_{\mathrm{i}}\right)$. Measurement of $p H$ using 5,5-dimethyl-2 $1^{14}$ Cloxalidine-2,4-dione (DMO): This method requires the measurement of the distribution of this radiolabelled weak acid between the intracellular space and an external medium of known pH. This was carried out as described previously (Goyal \& Gimmler 1989) using the silicone oil centrifugation technique to separate cells from incubation medium. Harvested cells were resuspended in media of required $\mathrm{pH}$ at a density of $1 \times$ $10^{6}$ cells $\mathrm{ml}^{-1}$. Cells were incubated with $0.95 \mu \mathrm{C}_{1}$ ${ }^{14} \mathrm{C}$-DMO in a total aliquot volume of $2.4 \mathrm{ml}$ in the light $\left(50 \mu \mathrm{mol} \mathrm{m} \mathrm{m}^{-2} \mathrm{~s}^{-1}\right)$ at room temperature $\left(18^{\circ} \mathrm{C}\right)$. A total of $50 \mu$ l of cell suspension was withdrawn and placed in a $400 \mu \mathrm{l}$ microfuge tube containing from bottom to top $50 \mu \mathrm{l} 0.75 \%(\mathrm{w} / \mathrm{v})$ sodium lauryl sulphate (SDS) in $1 \mathrm{M}$ glycine, $60 \mu \mathrm{l}$ Versilube $\mathrm{F} 50$ silicone oil (specific gravity 1.050 and 70 centistokes viscosity) and centrifuged in a Microfuge $B$ centrifuge (Beckman). The bottom portion of the tubes containing the cells was immediately frozen in liquid nitrogen, removed by razor blade, resuspended in $500 \mu l$ distilled water. Radioactivity was measured using $10 \mathrm{ml}$ scintillation fluid in a Beckman LS 6800 liquid scintillation counter. The intracellular space and free water space taken down with the cells through the silicone oil was estimated using $5 \mu \mathrm{M}$ ${ }^{14} \mathrm{C}$-inulin and ${ }^{3} \mathrm{H}_{2} \mathrm{O}$. Separate incubations with each were for 20 s. ${ }^{14} \mathrm{C}$ and ${ }^{3} \mathrm{H}$ activities in the pellet were determined by liquid scintillation counting. The intracellular space was determined as the total water volume minus the inulin permeable space. $\mathrm{pH}_{1}$ was calculated using the Henderson-Hasselbalch equation as described by Tromballa (1983).

Measurement of $\mathrm{pH}_{i}$ using 2'7'-bis(2-carboxyethyl)-5 (and -6) carboxyfluorescein acetomethylester (BCECF-AM): This was as described previously (Dixon et al. 1989). The final intracellular concentration of BCECF-AM was $5.0 \mu \mathrm{M}$. Cells were settled on a cover slip pretreated with poly-L-lysine (slide adhesive solution) and incubated for $2 \mathrm{~h}$ in the light $\left(50 \mu \mathrm{mol} \mathrm{m} \mathrm{m}^{-2}\right.$ $\mathrm{s}^{-1}$ ). A perfusion system was used to study the effect of 
external media on $\mathrm{pH}_{\mathrm{j}}$ on the same batch of cells under study.

Measurement of cell number. Cell number was determined using an improved Neubauer haemocytometer.

\section{RESULTS}

\section{Time course of ${ }^{14} \mathrm{C}$-DMO uptake by Emiliania huxleyi}

The relatively high surface area to volume ratio of Emiliania huxleyi cells allowed a rapid net influx of DMO, causing the cells to equilibrate with external DMO in less than 20 min at pH 8.3, 7.8 and 7.0 (Fig. 1). The final intracellular concentration of DMO was $7.5 \mu \mathrm{M}$.

\section{$\mathrm{pH}_{\mathrm{i}}$ in carbon-starved and $\mathrm{HCO}_{3}{ }^{-}$replete cells}

Comparison of the $\mathrm{pH}_{1}$ using the DMO and the fluorescent probe technique for high-calcifying cells of Emiliania huxleyi (88E) at an external pH of 8.3 in the presence or absence of $\mathrm{HCO}_{3}^{-}$gave similar values (Table 1). In the presence of $2 \mathrm{mM} \mathrm{HCO}_{3}^{-}$the $\mathrm{pH}_{\mathrm{i}}$ of cells was 7.03 using the fluorescent probe and 6.77 by the DMO method. With carbon-starved cells the $\mathrm{pH}_{1}$ fell to 6.33 , measured by the fluorescent probe technique and to 6.15 by the DMO method. The $\mathrm{pH}_{1}$ measured by the fluorescent probe technique was marginally higher than that measured by the DMO method (Table 1).

\section{$\mathrm{pH}_{\mathrm{i}}$ in relation to $\mathrm{CO}_{2}$ availability}

Cells were grown at different air-equilibrated levels of $\mathrm{CO}_{2}\left(0.03,0.1\right.$ and $0.5 \% \mathrm{v} / \mathrm{v} \mathrm{CO}_{2}$ /air maintaining the $\mathrm{pH}$ of the medium constant using organic buffers. Growth was not observed with $0.5 \%$ (v/v) $\mathrm{CO}_{2} /$ air while $0.1 \%$ (v/v) $\mathrm{CO}_{2} /$ air reduced the growth rate from 0.3 to 0.23 divisions $\mathrm{d}^{-1}$ producing approximately $65 \%$ of the final cell biomass of cultures grown on air levels of $\mathrm{CO}_{2}(0.03 \% \mathrm{v} / \mathrm{v} \mathrm{CO}$ /air) (Fig 2). In contrast to elevated $\mathrm{CO}_{2}$ concentrations, decreasing the $\mathrm{CO}_{2}$ concentration to minimal levels in the culture medium did not affect the growth of the high-calcifying cells of Emiliania huxleyi (Fig. 2).

Cells were grown at $\mathrm{pH} 8.3$ at 2 different $\mathrm{CO}_{2}$ concentrations to investigate the effect of $\mathrm{CO}_{2}$-enriched air on $\mathrm{pH}_{1}$. The $\mathrm{pH}_{\mathrm{i}}$ (measured by ${ }^{14} \mathrm{C}-\mathrm{DMO}$ ) dropped by approximately $0.4 \mathrm{pH}$ units from 6.77 when grown at air levels of $\mathrm{CO}_{2}\left(0.03 \% \mathrm{v} / \mathrm{v} \mathrm{CO}_{2} /\right.$ air $)$ to 6.38 when cells were grown at $0.1 \%$ (v/v) $\mathrm{CO}_{2} /$ air (Table 2 ).

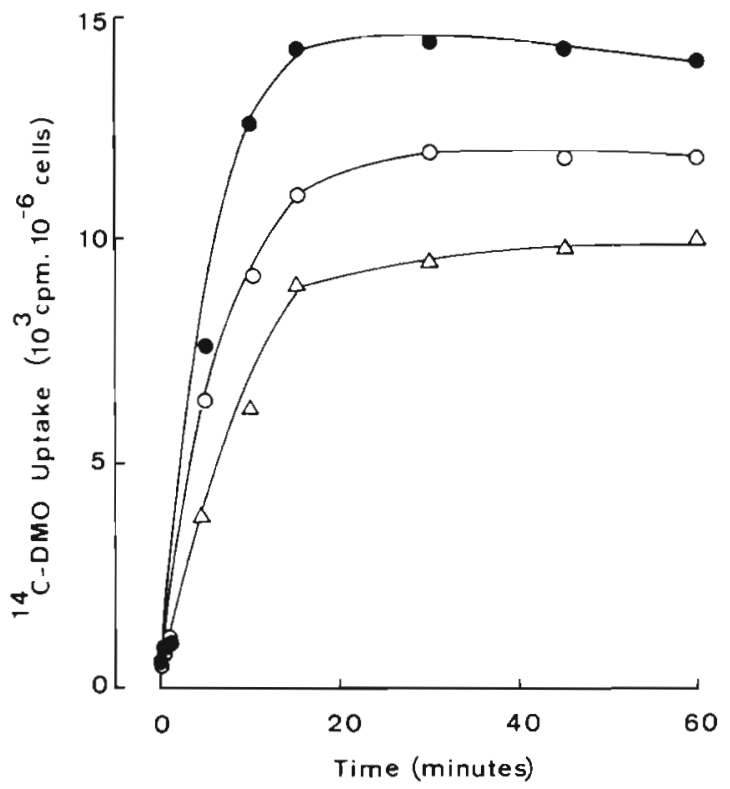

Fig. 1. Emiliania huxleyi. Time course of ${ }^{14} \mathrm{C}$-DMO uptake by high-calcifying cells at pH $8.3(0), 7.8(0)$ and $7.0(\Delta)$

\section{External $\mathrm{pH}, \mathrm{pH}_{\mathrm{i}}$ and growth}

The growth rate was reduced to 0.25 divisions $d^{-1}$ in cultures at external $\mathrm{pH} 7.8$ and to 0.16 divisions $\mathrm{d}^{-1}$ at external pH 7.0 (Fig. 3). In cells growing at external $\mathrm{pH} 7.0$ the $\mathrm{pH}_{1}$ was 6.19 in mid growth phase, declined to 6.07 by late growth phase and was maintained at this value throughout the stationary phase. At external $\mathrm{pH} 7.8, \mathrm{pH}_{\mathrm{i}}$ was 6.52 at mid growth phase, declined to 6.41 by late growth phase and to 6.32 by the end of

Table 1. Emiliania huxleyi. Effect of the presence of $2 \mathrm{mM}$ $\mathrm{HCO}_{3}{ }^{-}$on $\mathrm{pH}_{1}$ in high-calcifying cells using the fluorescent probe technique and the DMO method (growth media as described in 'Material and methods')

\begin{tabular}{|c|c|c|}
\hline \multirow{2}{*}{ Treatment } & \multicolumn{2}{|c|}{$\mathrm{pH}_{1}$ measured by: } \\
\hline & $\begin{array}{l}\text { Fluorescent probe } \\
\text { technique }\end{array}$ & DMO method ${ }^{b}$ \\
\hline $\begin{array}{l}\text { Growth media } \\
\text { with } 2 \mathrm{mM} \mathrm{HCO}_{3}^{-}\end{array}$ & $7.03 \pm 0.14$ & $6.77 \pm 0.31$ \\
\hline $\begin{array}{l}\text { Growth media } \\
\text { lacking } \mathrm{HCO}_{3}^{-}\end{array}$ & $6.33 \pm 0.12$ & $6.15 \pm 0.29$ \\
\hline \multicolumn{3}{|c|}{$\begin{array}{l}{ }^{a} \text { Intracellular } \mathrm{pH} \text { monitored as the average ( } \pm \mathrm{SE} \text { ) } 480 / 450 \\
\text { excitation ratio of several (10) E. huxleyicells loaded with } \\
\text { the ratiometric } \mathrm{pH} \text { indicator BCECF (Dixon et al. } 1989 \text { ). } \\
\text { Cells were immobilized on } 0.01 \% \text { poly-L-lysine coated } \\
\text { coverslips } \\
\text { boints represent the average ( } \pm \mathrm{SE} \text { ) of } 3 \text { replicate read- } \\
\text { ings }\end{array}$} \\
\hline
\end{tabular}




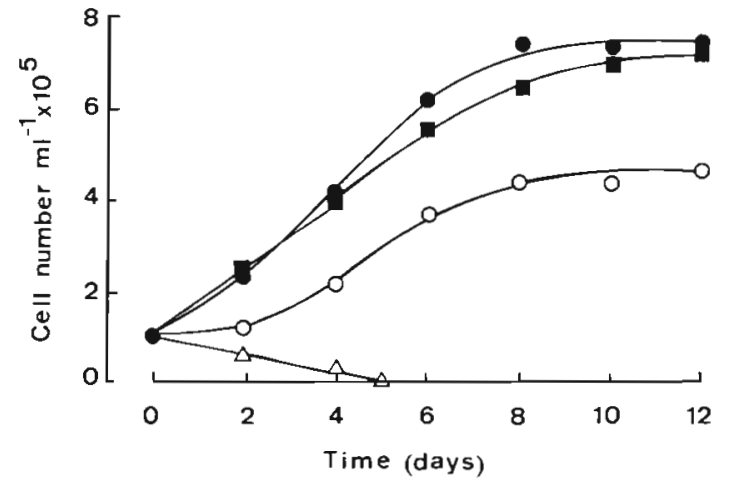

Fig. 2. Emiliania huxleyi. Growth of high-calcifying cells in relation to $\mathrm{CO}_{2}$ concentration. Cell number in cultures grown at air levels of $\mathrm{CO}_{2}\left(0.03 \% \mathrm{v} / \mathrm{v} \quad \mathrm{CO}_{2} /\right.$ air $)(0), 0.1 \%(\mathrm{v} / \mathrm{v})$ $\mathrm{CO}_{2}$ /air (O), 0.5\% (v/v) $\mathrm{CO}_{2} /$ air $(\Delta)$ and $\mathrm{CO}_{2}$-free air (ם). All cultures grown at $15^{\circ} \mathrm{C}, 2 \mathrm{mM}$ dissolved inorganic carbon, $20 \mu \mathrm{M} \mathrm{NO}_{3}^{-}, \mathrm{pH} 8.3,50 \mu \mathrm{mol} \mathrm{m} \mathrm{m}^{-2} \mathrm{~s}^{-1}$ photon flux density. Points represent the average of 3 replicate readings

stationary phase. When cells were grown at $\mathrm{pH} 8.3$ the $\mathrm{pH}_{\mathrm{i}}$ at mid growth phase was 6.77 , which was maintained almost unchanged during late growth phase and stationary phase (Table 2).

\section{DISCUSSION}

Possible limitations of the DMO technique has been reviewed (Boron \& Roos 1976, De Michelis et al. 1979, Gimmler \& Hartung 1988, Goyal \& Gimmler 1989). In the present study the DMO method and the fluorescent probe technique gave comparable results and provided reliable methods for $\mathrm{pH}_{\mathrm{i}}$ measurements in highcalcifying cells of Emiliania huxleyi. The fluorescent probe technique has the advantage that it allows mea-

Table 2. Emiliania huxleyi. Effect of growth media $\mathrm{pH}$ and different $\mathrm{CO}_{2}$ concentrations at $\mathrm{pH} 8.3$ on $\mathrm{pH}_{1}$ of high-calcifying cells using the DMO method at different stages of culture growth. Values represent the average $( \pm \mathrm{SE}$ ) of 3 replicate readings

\begin{tabular}{|c|c|c|c|}
\hline $\begin{array}{l}\text { External } \\
\mathrm{pH}\end{array}$ & $\begin{array}{l}\text { Mid growth } \\
\text { phase }\end{array}$ & $\begin{array}{l}\text { Late growth } \\
\text { phase }\end{array}$ & $\begin{array}{l}\text { Stationary } \\
\text { phase }\end{array}$ \\
\hline $\begin{array}{l}\mathrm{pH} 7.0 \\
0.03 \%(\mathrm{v} / \mathrm{v}) \mathrm{CO}_{2} / \mathrm{c}\end{array}$ & $\begin{array}{l}6.19 \pm 0.15 \\
\text { air }\end{array}$ & $6.07 \pm 0.10$ & $6.08 \pm 0.17$ \\
\hline $\begin{array}{l}\mathrm{pH} 7.8 \\
0.03 \%(\mathrm{v} / \mathrm{v}) \mathrm{CO}_{2} / \mathrm{a}\end{array}$ & $\begin{array}{l}6.52 \pm 0.23 \\
\text { air }\end{array}$ & $6.41 \pm 0.24$ & $6.32 \pm 0.19$ \\
\hline $\begin{array}{l}\mathrm{pH} 8.3 \\
0.03 \%(\mathrm{v} / \mathrm{v}) \mathrm{CO}_{2} / \mathrm{a}\end{array}$ & $6.77 \pm 0.13$ & $6.71 \pm 0.20$ & $6.75 \pm 0.30$ \\
\hline $\begin{array}{l}\mathrm{pH} 8.3 \\
0.1 \%(\mathrm{v} / \mathrm{v}) \mathrm{CO}_{2} / \mathrm{ai}\end{array}$ & $r$ & $6.35 \pm 0.24$ & $6.37 \pm 0.18$ \\
\hline
\end{tabular}

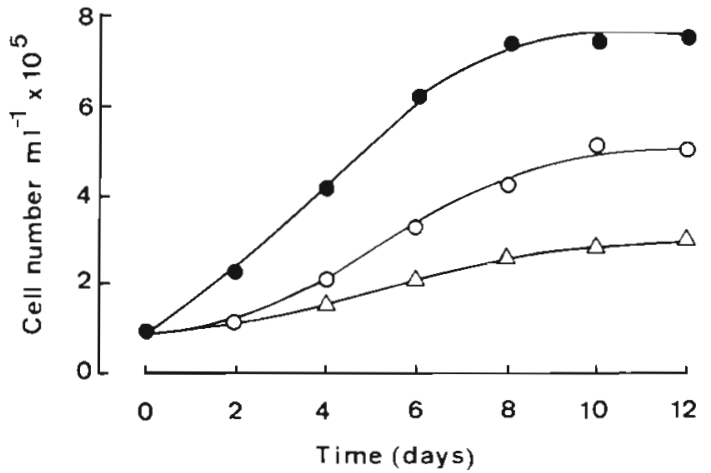

Fig. 3. Emiliania huxleyi. Growth of high-calcifying cells in response to different external $\mathrm{pH}$. Cell number in cultures grown at air levels of $\mathrm{CO}_{2}(0.03 \% \mathrm{v} / \mathrm{v} \mathrm{CO} /$ air $)$ at $\mathrm{pH} 8.3(0)$, $\mathrm{pH} 7.8(0)$ and $\mathrm{pH} 7.0(\triangle)$. All cultures grown at $15^{\circ} \mathrm{C} .2 \mathrm{mM}$ dissolved organic carbon, $20 \mu \mathrm{M} \mathrm{NO}_{3}^{-}, 50 \mu \mathrm{mol} \mathrm{m} \mathrm{m}^{-2} \mathrm{~s}^{-1}$ photon flux density. Points represent the average of 3 replicate readings

surement of the spatial and temporal variation in $\mathrm{pH}$ of a single cell and the rapid change in $\mathrm{pH}_{1}$ in response to external conditions.

Cytoplasmic pH in the high-calcifying cells of Emiliania huxleyi (Table 1) is more acidic than that reported for other plant cells (Smith 1979, Raven 1980) and other non-calcifying marine microalgae (Raven \& Smith 1980, Burns \& Beardall 1987) but is similar to values found for the low-calcifying cells (Dixon et al. 1989) with a $\mathrm{pH}_{1}$ near neutrality. This suggests that the optimum $\mathrm{pH}_{1}$ for cellular metabolic pathways in E. huxleyi may be different from some other algae. The dependence of various enzyme activities on $\mathrm{pH}$ relies mainly on enzyme protonation, a critical process for their biological function, which is controlled by $\mathrm{pH}$ (Haussinger et al. 1988).

$\mathrm{pH}_{\mathrm{i}}$ was strongly dependent on the availability of $\mathrm{HCO}_{3}{ }^{-}$in the medium. With both $\mathrm{pH}$ measurement techniques the addition of $\mathrm{HCO}_{3}{ }^{-}$to carbon-starved cells resulted in an increase in $\mathrm{pH}_{1}$ while its removal resulted in the cytosolic acidification, suggesting a role of $\mathrm{HCO}_{3}{ }^{-}$in buffering cytosolic $\mathrm{pH}$. $\mathrm{HCO}_{3}^{-}$influx (Sikes \& Wilbur 1982, Nimer \& Merrett 1992) was shown previously to be very rapid (Nimer \& Merrett 1992). The rise in $\mathrm{pH}_{\mathrm{i}}$ in the presence of $\mathrm{HCO}_{3}{ }^{-}$might be due to an increase in $\mathrm{OH}^{-}$in the cytosol as a result of the production of $\mathrm{CO}_{2}$ from $\mathrm{HCO}_{3}{ }^{-}$occurring in the chloroplast or the cytosol (Nimer \& Merrett 1993, Brownlee et al. 1994b). However, if $\mathrm{HCO}_{3}{ }^{-}$transport across the plasmalemma was coupled to the export of $\mathrm{OH}^{-}$or influx of $\mathrm{H}^{+}$, cytosolic alkalinization during $\mathrm{HCO}_{3}{ }^{-}$uptake would not be expected. Calcification in high-calcifying cultures of Emiliania huxleyi in a simulated seawater medium results in rapid utilization of dissolved inorganic carbon (DIC), largely as $\mathrm{HCO}_{3}{ }^{-}$, 
but external pH remains unaltered (Dong et al. 1993, Merrett et al. 1993) while alkalinity decreases. This suggests the absence of a $\mathrm{HCO}_{3}^{-} / \mathrm{OH}^{-}$antiport or $\mathrm{HCO}_{3}{ }^{-} / \mathrm{H}^{+}$symport at the plasmalemma.

$\mathrm{CO}_{2}$ exerts a dual effect on $\mathrm{pH}_{1}$. First, it will lower $\mathrm{pH}_{\mathrm{i}}$. Since it can diffuse passively across the plasmalemma, if it is present externally at higher concentrations, a state of equilibrium has to be reached. Second, $\mathrm{CO}_{2}$ fixation by Rubisco will have the primary effect of increasing $\mathrm{pH}_{i}$ by removing $\mathrm{CO}_{2}$; but, as a result of $\mathrm{CO}_{2}$ fixation by Rubisco, a larger metabolic effect can be observed, owing to the accumulation of acidic products. This was observed when cells were grown on media of different external $\mathrm{pH}$, so that, at more acidic $\mathrm{pH}, \mathrm{pH}_{1}$ was lower and this was reflected in a decrease in growth rates. High-calcifying cells of Emiliania huxleyi show lower photosynthetic oxygen evolution at more acidic pH (Nimer \& Merrett 1992). When external $\mathrm{pH}$ was buffered at $\mathrm{pH} 8.3$ and $\mathrm{CO}_{2}$ levels increased from 0.03 to $0.1 \%(\mathrm{v} / \mathrm{v}) \mathrm{CO}_{2} /$ air, $\mathrm{pH}_{1}$ and growth rate decreased while at $0.5 \%$ (v/v) $\mathrm{CO}_{2}$ /air high-calcifying cells failed to grow, in part because of the decrease in $\mathrm{pH}_{\mathrm{i}}$. Many species of marine phytoplankton restrict intracellular $\mathrm{pH}$ to between 7.0 and 7.4 by ion transport mechanisms and a high buffering capacity of the cytosol and these show enhanced growth at elevated $\mathrm{CO}_{2}$ concentrations (Beardall \& Raven 1981, Gehl \& Colman 1985, Sultemeyer et al. 1989). The inhibition of growth of the high-calcifying cells of E. huxleyi at elevated $\mathrm{CO}_{2}$ may be related to the inability to generate adequate $\mathrm{OH}^{-}$to neutralize the protons produced by calcification (Nimer \& Merrett 1993) and to counteract the acidification of the cytosol resulting from the passive diffusion of $\mathrm{CO}_{2}$ at elevated ambient concentrations.

The response of Emiliania huxleyi to $\mathrm{CO}_{2}$ and $\mathrm{HCO}_{3}^{-}$(Dong et al. 1993) may be one of several parameters that interact in the development of $E$. huxleyi blooms. Field studies show coccolithophore blooms succeed spring diatom blooms (Holligan et al. 1983) when these become limited by nutrient depletion of the upper mixed layer. The depletion in $\mathrm{CO}_{2}$ following the spring diatom bloom (Codispoti et al. 1982) would favour E. huxleyi since it is able to obtain the carbon for growth and calcification from $\mathrm{HCO}_{3}^{-}$(Dong et al. 1993) and has a very short generation time compared to other calcifying phototrophs. The generation of $\mathrm{CO}_{2}$ from $\mathrm{HCO}_{3}{ }^{-}$in calcification may also confer advantages in terms of photon and nutrient costs of carbon fixation in calcifying cells (Brownlee et al. 1994a) compared to phytoplankton with $\mathrm{CO}_{2}$-concentrating mechanisms (Raven \& Johnston 1991). However, conditions at the beginning of a spring diatom bloom might also be expected to favour growth of $E$. huxleyi since recent studies suggest the diffusive $\mathrm{CO}_{2}$ flux to the surface of a diatom cell may be rate limiting for growth (Riebesell et al. 1993). It is possible that diatoms also have the potential to use bicarbonate (Patel \& Merrett 1986 , Dixon \& Merrett 1988) or alternatively that the $\mathrm{CO}_{2}$ concentration may be important at the beginning of a spring bloom. The growth of calcifying cells of $E$. huxleyi is inhibited at external $\mathrm{CO}_{2}$ concentrations that increase the growth rate of diatoms and this differential effect may occur at the onset of a spring bloom giving a faster growth rate for diatoms than for E. huxleyi.

Acknowledgement. This work was supported by the EEC funding to the MAS2-CT92-0038 project.

\section{LITERATURE CITED}

Beardall, J., Raven, J. A. (1981). Transport of inorganic carbon and the $\mathrm{CO}_{2}$ concentrating mechanism in Chlorella emersonii (Chlorophyceae). J. Phycol. 17: 134-141

Boron, W. F., Roos, A. (1976). Comparison of microelectrode, DMO and methylamine methods for measuring intracellular pH. Am. J. Physiol. 231: 118-123

Brand, L. E. (1982). Genetic variability and spatial patterns of genetic differentiation in the reproductive rates of the marine coccolithophores Emiliania huxleyi and Gephyrocapsa oceanica. Limnol. Oceanogr. 27: 236-245

Brownlee, C., Davies, M., Nimer, N., Dong, L. F., Merrett, M. J. (1994a). Calcification, photosynthesis and intracellular regulation in Emiliania huxleyi. Bull. Inst. océanogr. Monaco 13: (in press)

Brownlee, C., Nimer, N. A., Dong, L. F., Merrett, M. J. (1994b). Cellular regulation during calcification in Emiliania huxleyi. In: Green, J., Leadbeater, B. (eds.) Biology of Prymnesiophytes. Syst. Soc. (in press)

Burns, B. D., Beardall, J. (1987). Utilization of inorganic carbon by marine microalgae. J. exp. Biol. Ecol. 107: 75-86

Codispoti, L. A., Friederich, G. E., Iverson, R. L., Hood, D. W. (1982). Temporal changes in the inorganic carbon system of the south-eastern Bering sea during spring 1980. Nature 296: 242-245

Coleman, J. R., Colman, B. (1981). Inorganic carbon accumulation and photosynthesis in a blue green alga as a function of external pH. Plant Physiol. 67: 917-921

De Michelis, M. I., Raven, J. A., Jayasuriya, H. D. (1979). Measurement of cytoplasmic $\mathrm{pH}$ by the DMO technique in Hydrodictyon africanum. J. exp. Bot. 30:681-695

Dixon, G. K., Brownlee, C., Merrett, M. J. (1989). Measurement of internal $\mathrm{pH}$ in the coccolithophore Emiliania huxleyi using 2 $7^{\prime}$-bis-(carboxyethyl)-5 (and -6) carboxyfluorescein acetoxymethylester and digital imaging microscopy. Planta 178: 443-449

Dixon, G. K., Merrett, M. J. (1988). Bicarbonate utilization by the marine diatom Phaeodactylum tricornutum Bohlin. New Phytol. 109: 47-51

Dixon G. K., Patel, B. N., Merrett, M. J. (1987). Role of intracellular carbonic anhydrase in inorganic carbon assimilation by Porphyridium purpureum. Planta 172: 508-513

Dong, L. F., Nimer, N. A., Okus, E., Merrett, M. J. (1993). Dissolved inorganic carbon utilization in relation to calcite production in Emiliania huxleyi (Lohmann) Kamptner. New Phytol. 123: 679-684

Falkner, G., Horner, F., Werdan, K., Heldt, H. W. (1976). pH changes in the cytoplasm of the blue green alga Anacystis 
nidulans caused by light-dependent proton flux into the thylakoid space. Plant Physiol. 58: 717-718

Gehl, K. A., Colman, B. (1985). Effect of external pH on the internal pH of Chlorella saccharophila. Plant Physiol. 77: 917-921

Gimmler, H., Hartung, W. (1988). Low permeability of the plasma membrane of Dunaliella parva for solutes. J. Plant Physiol. 133: 165-172

Gimmler, H., Kugel, H., Leibfritz, D., Mayer, A. (1988). Cytoplasmic pH of Dunaliella parva and Dunaliella acidophila as monitored by in vivo ${ }^{31} \mathrm{P}$-NMR spectroscopy and the DMO method. Physiol. Plant 74: 521-530

Goyal, A., Gimmler, H. (1989). Osmoregulation in Dunaliella tertiolecta effects of salt stress and external $\mathrm{pH}$ on the internal pH. Arch. Microbiol. 152: 138-142

Haussinger, D., Gerok, W., Guder, W., Silbernagl, S., Sies, H. (1988). Why $\mathrm{pH}$ homeostasis. In: Hasssinger D. (ed.) pH homeostasis mechanisms and control. Academic Press, London, p. 1-4

Holligan, P. M., Viollier, M., Harbour, D. S., Camus, P., Champagne-Philippe, M. (1983). Satellite and ship studies of coccolithophore production along a continental shelf edge. Nature 304: 339-342

Lane, A. E., Burris, J. E. (1981). Effects of environmental pH on the internal $\mathrm{pH}$ of Chlorella pyrenoidosa, Scenedesmus quadricauda and Euglena gracilis. Plant Physiol. 68: 439-442

Merrett, M. J., Dong, L. F., Nimer, N. A. (1993). Nitrate availabilty and calcite production in Emiliania huxleyi Lohmann. Eur. J. Phycol. 28: 243-246

Nimer, N. A., Dixon, G. K., Merrett, M. J. (1992). Utilization of inorganic carbon by the coccolithophorid Emiliania huxleyi (Lohmann) Kamptner. New Phytol. 120: 153-158

Nimer, N. A., Merrett, M. J (1992). Calcification and utilization of inorganic carbon by the coccolithophorid Emiliania huxleyi. New Phytol. 121: 173-177

Nimer, N. A., Merrett, M. J. (1993). Calcification rate in Emiliania huxleyi Lohmann in response to light, nitrate and availability of inorganic carbon. New Phytol. 123: 673-677

Patel, B. N., Merrett, M. J. (1986). Inorganic carbon uptake by the marine diatom Phaeodactylum tricornutum. Planta 169: $222-227$

This article was submitted to the editor
Raven, J. A. (1980). Nutrient transport in microalgae. Adv. microb. Physiol. 21: 1357-1369

Raven, J. A., Johnston, A. M. (1991). Mechanisms of inorganic carbon acquisition in marine phytoplankton and their implications for the use of other resources. Limnol. Oceanogr. 36: 1701-1714

Raven, J. A., Smith, F. A. (1974). Significance of hydrogen ion transport in plant cells. Can. J. Bot. 52: 1035-1048

Raven, J. A., Smith, F. A. (1976). Cytoplasmic pH regulation and electrogenic $\mathrm{H}^{+}$extrusion. Curr. Adv. Plant Sci. 8: $649-659$

Raven, J. A., Smith, F. A. (1980). Intracellular pH regulation in the giant celled marine alga Chaetomorpha darwinii. J. exp. Bot. 31: 1357-1369

Rees, T. A. V. (1984). Sodium dependent photosynthetic oxygen evolution in a diatom. J. exp. Bot. 35: 332-337

Riebesell, U., Wolf-Gladrow, D. A., Smetacek, V. (1993). Carbon dioxide limitation of marine phytoplankton growth rates. Nature 361: 249-251

Shiraiwa, Y., Satoh, H., Hirokawa, T. (1988). Factors controlling induction of carbonic anhydrase in Chlorella vulgaris. Effects of $\mathrm{CO}_{2}$ and $\mathrm{O}_{2}$. Plant Cell Physiol. 29: 731-734

Sikes, C. S., Wilbur, K. M. (1982). Functions of coccolith formation. Limnol. Oceanogr. 27: 18-26

Sikes, C. S., Roer, R. D., Wilbur, K. M. (1980). Photosynthesis and coccolith formation: inorganic carbon sources and net inorganic reaction of deposition. Limnol. Oceanogr. 25: 248-261

Smith, F. A. (1979). Comparison of the effects of ammonia and methylamine on chloride transport and intracellular $\mathrm{pH}$ in Chara corrallina. J. exp. Bot. 31:597-606

Sultemeyer, D. F., Miller, A. G., Espie, G. S., Fock, H. P., Canvin, D. T (1989). Active $\mathrm{CO}_{2}$ transport by the green alga Chlamydomonas reinhardtii. Plant Physiol. 89: 1213-1219

Tester, M. (1990). Plant ion channels: whole-cell and singlechannel studies. New Phytol. 114: 305-340

Tromballa, $\mathrm{H}$. W. (1983). The effect of $\mathrm{CO}_{2}$ on potassium transport by Chlorella fusca. Plant Cell Environ. 6: 537-543

Umino, Y., Satoh, A., Shiraiwa, Y. (1991). Factors controlling induction of external carbonic anhydrase and changes in $\mathrm{K}_{0.5}\left(\mathrm{CO}_{2}\right)$ of photosynthesis in Chlorella regularis. Plant Cell Physiol. 32: 379-384

Manuscript first received: December 6, 1993

Revised version accepted: April 25, 1994 